\title{
Customised crescentic corneal transplant with conjunctival resection in an atypical case of malignant Mooren's ulcer
}

Jayanand Urkude, Rashmi Singh, Manthan Chaniyara, Amar Pujari

Dr. Rajendra Prasad Centre for Ophthalmic Sciences, AlIMS, New Delhi, India

\section{Correspondence to} Dr Jayanand Urkude, drjay2910@gmail.com

Accepted 25 June 2017
CrossMark

\footnotetext{
To cite: Urkude J, Singh R, Chaniyara $\mathrm{M}$, et al. BMJ Case Rep Published Online First: [please include Day Month Year]. doi:10.1136/bcr-2017 220973
}

\section{DESCRIPTION}

Mooren's ulcer is a painful peripheral ulcerative keratitis of unknown aetiology. It is rapidly progressive inflammatory destruction of the juxtalimbal corneal stroma with no associated scleritis. Mooren's ulcer is a diagnosis of exclusion, after ruling out all the relevant systemic and local causes that lead to peripheral ulcerative keratitis. It usually present as bilateral disease with male to female distribution of 1:0.74 being more common in older age group. ${ }^{1}$ Mooren's ulcer has been seen to be associated with human leucocyte antigen (HLA)DR17(3) and DQ2.

A 20-year-old male patient presented with complaints of sudden onset pain, redness and watering in the left eye. History revealed recurrent episodes of similar complaints for the last 2 years. On examination, the visual acuity in the left eye was counting finger at $2 \mathrm{~m}$ and $20 / 20$ in the right eye. The slit-lamp biomicroscopic examination showed juxtalimbal severe congestion associated with $2 \times 2 \mathrm{~mm}$ of perforation between 8 and 9 clock hours with uveal tissue prolapsed (figure 1A). Peripheral corneal thinning extending from 4 to 11 clock hours involved $90 \%$ of the
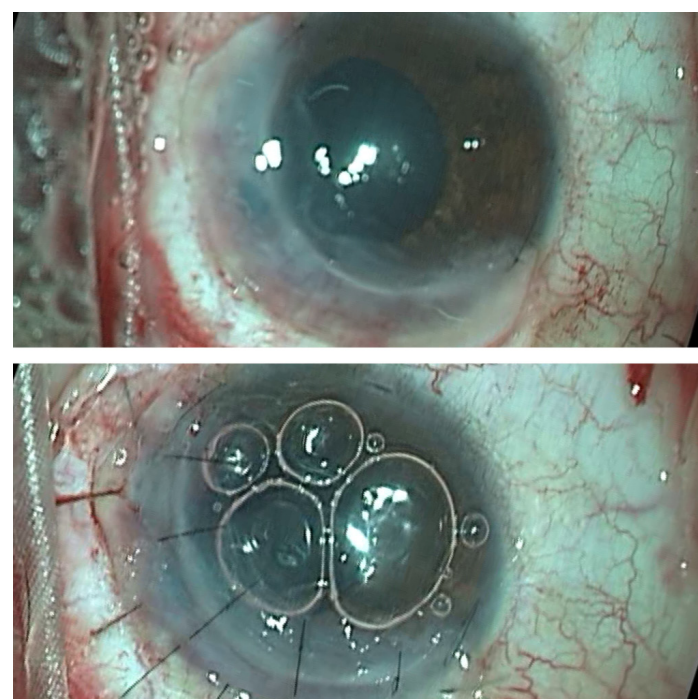

Figure 2 (A) Intraoperatively customised corneal graft tucked in the peripheral gutter with the help of fibrin glue. (B) Well-apposed crescentic corneal graft after putting 10-0 monofilament nylon sutures.
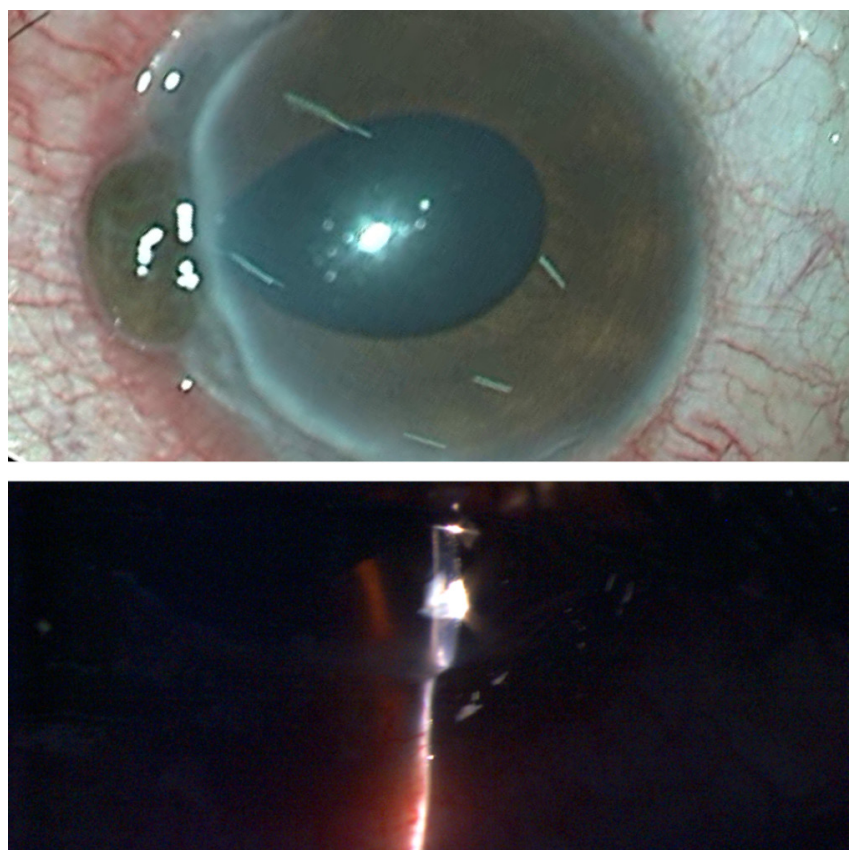

Figure 1 (A) Clinical picture showing peripheral corneal gutter extending from 4 to 11 clock hours along with perforation and uveal tissue prolapsed between 8 and 9 clock hours. (B) Slit-lamp biomicroscopy examination showing peripheral corneal thinning involving up to $90 \%$ of the stroma. 

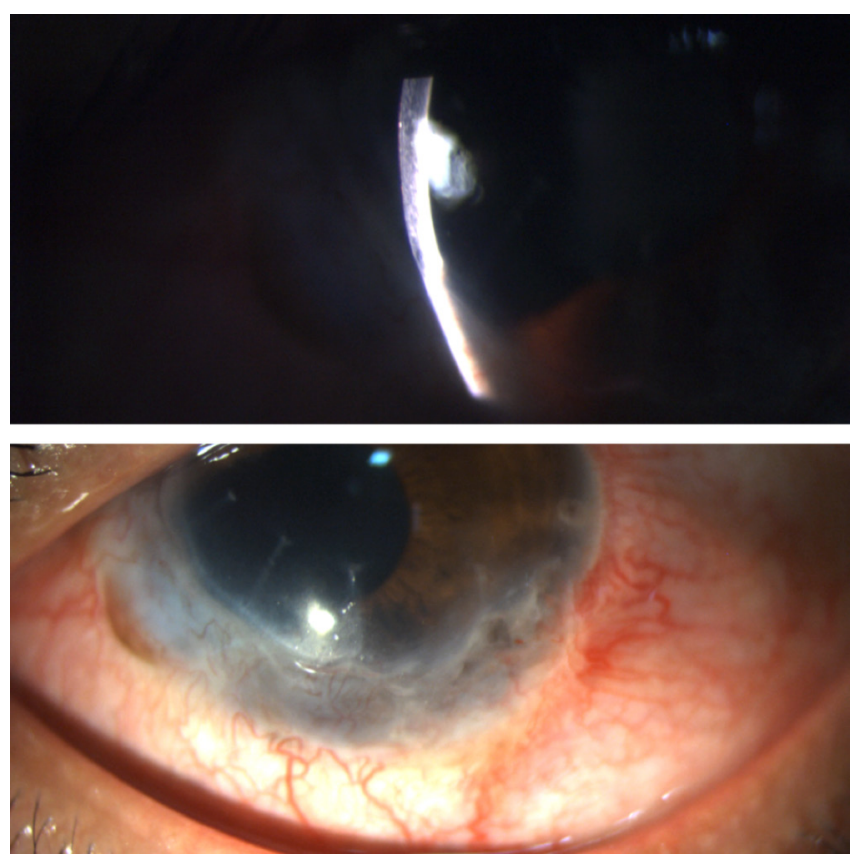

Figure 3 (A) Slit-lamp picture showing improved corneal thinning at the end of 5 months. (B) Clinical picture showing well taken corneal graft without any activity.

stroma with an overhanging edge (figure 1B). On fluorescence staining, an epithelial defect was present throughout the gutter; the Seidel test was positive with an irregular anterior chamber depth. Fundus examination was done which revealed no obvious retinal pathology. Other eye had no signs of ulcerative keratitis. Scraping and culture from affected area of cornea did not show any micro-organism. Preoperative detail systemic workup including complete blood count, fasting and postprandial blood sugar, liver function tests, renal function tests, tuberculin skin test, chest X-ray, sacroiliac joint X-ray, rheumatoid factor, angiotensin converting enzyme, venereal disease research laboratory test, hepatitis B and C surface antigen, HIV-1, HIV-2, antineutrophil cytoplasmic antibody assay, antinuclear antibody assay, routine, microscopic examination of urine and stool were performed, however all test results were within normal limit. Based on our examination and investigative findings, a diagnosis of an atypical case of Mooren's ulcer was made and the patient was started on eye drop (e/d) prednisolone sodium phosphate 1\% 2 hourly and oral prednisolone at a dose $1 \mathrm{mg} / \mathrm{kg} /$ body weight per day. As there was perforation with uveal tissue prolapse with surrounding necrotic cornea, customised crescentic corneal grafting with limited conjunctival resection was performed under general anaesthesia using fibrin-based biological tissue

\section{Learning points}

- Mooren's ulcer is a diagnosis of exclusion, its atypical presentation with vision threatening scenario needs awareness.

- Because of the peripheral corneal localisation of the pathology, the emphasis should be given to decrease the immune complex load at the periphery by conjunctival resection along with immunosuppressants.

- The cases with severe thinning and corneal perforation need urgent intervention in terms tectonic support for a better visual outcome.

adhesive (figure 2A) and additional support was provided with interrupted 10-0 monofilament nylon sutures(figure $2 \mathrm{~B}$ ). Postoperatively disease showed signs of healing with no recurrence. The topical and oral steroids were tapered after 2 weeks of appearance of healing signs. At the end of 5 months, best corrected visual acuity was 20/40 with well-taken graft in the absence of any activity of disease (figure 3A,B).

Earlier Wood and Kaufman have classified Mooren's ulcer into two types; benign type is usually unilateral seen in elderly patients with good response to medical treatment while the malignant type is usually bilateral and present in younger patients with a more aggressive form which is resistant to medical treatment. ${ }^{3}$ In our case, it was aggressive unilateral disease in a young patient. Mooren's ulcer is basically an autoimmune disease; the management protocol of Mooren's ulcer involves prevention of immune complex infiltration into the adjacent corneal stroma. Medical management of mild to moderate cases includes topical steroids along with immunomodulator like ciclosporin. In severe cases with extreme corneal thinning and perforation, the aim is to provide tectonic support and also to prevent immune complex entering into the cornea. Simultaneous systemic steroid, along with immunosuppressive drugs with methotrexate, cyclophosphamide may be necessary. In our case, hand fashioned full thickness corneal graft along with limited conjunctival resection slowed the disease progression and maintained the anatomical integrity with the good visual outcome at end of 5 months.

\section{Competing interests None declared.}

Patient consent Obtained.

Provenance and peer review Not commissioned; externally peer reviewed.

(c) BMJ Publishing Group Ltd (unless otherwise stated in the text of the article). All rights reserved. No commercial use is permitted unless otherwise expressly granted.

\section{REFERENCES}

1 Chen J, Xie H, Wang Z, et al. Mooren's ulcer in China: a study of clinical characteristics and treatment. Br J Ophthalmo/ 2000;84:1244-9.

2 Taylor CJ, Smith SI, Morgan CH, et al. HLA and Mooren's ulceration. Br J Ophthalmol 2000;84:72-5.

3 Wood TO, Kaufman HE. Mooren's ulcer. Am J Ophthalmol 1971;71:417-22. 
Copyright 2017 BMJ Publishing Group. All rights reserved. For permission to reuse any of this content visit http://group.bmj.com/group/rights-licensing/permissions.

BMJ Case Report Fellows may re-use this article for personal use and teaching without any further permission.

Become a Fellow of BMJ Case Reports today and you can:

- Submit as many cases as you like

- Enjoy fast sympathetic peer review and rapid publication of accepted articles

Access all the published articles

Re-use any of the published material for personal use and teaching without further permission

For information on Institutional Fellowships contact consortiasales@bmjgroup.com

Visit casereports.bmj.com for more articles like this and to become a Fellow 